\title{
Quiescent-phase dynamics and surge history of a polythermal glacier: Hessbreen, Svalbard
}

\author{
Monica SUND, ${ }^{1}$ Trond EIKEN ${ }^{2}$ \\ ${ }^{1}$ Norwegian Water Resources and Energy Directorate, P.O. Box 5091 Majorstua, N-0301 Oslo, Norway \\ E-mail: mosu@nve.no \\ ${ }^{2}$ Department of Geosciences, University of Oslo, P.O. Box 1047 Blindern, N-0316 Oslo, Norway
}

\begin{abstract}
Hessbreen is a $5 \mathbf{~ k m}^{2}$, polythermal glacier in southern Spitsbergen. It is believed to have surged at the end of the 19th century, and another surge started in 1969, not in 1972 as earlier studies suggested. The surge was probably triggered in the middle section of the glacier and affected the upper part approximately 4 years before including the whole glacier. Present velocities are low, increasing from $0.3 \mathrm{~m} \mathrm{a}^{-1}$ at the snout to $4.8 \mathrm{~m} \mathrm{a}^{-1}$ above the equilibrium line. A distinct velocity reduction occurs where the glacier narrows. This suggests the velocities here are affected by the cold marginal and frontal ice. Large seasonal variations, with summer velocities of more than twice the winter velocities in the middle part of the glacier, indicate a seasonal change in the drainage system in this area. In the lower part there is no apparent sliding. The balance-flux estimate indicates that the actual ice flux is only about $50 \%$ of that required for steady state, so Hessbreen appears to be building up in the accumulation area. The surge duration is now estimated to be 8 years.
\end{abstract}

\section{INTRODUCTION}

Surge behaviour is characterized by cyclical instabilities related to internal changes in the glacier system rather than external factors such as climate change (Meier and Post, 1969), although the mechanism responsible for surge behaviour is still debated. Two major mechanisms have been proposed, one involving a thermal trigger (e.g. Schytt, 1969; Clarke, 1976) and one involving subglacial hydrology (e.g. Clarke and others, 1984; Kamb and others, 1985). Glacier dynamics, not only during the surge phase, but also during the quiescent phase, are of importance in understanding surge behaviour.

Svalbard is an Arctic archipelago, of which about $60 \%$ is covered by glaciers (Hagen and others, 1993). The Svalbard glaciers are classified as polythermal (Schytt, 1969; Björnsson and others, 1996). It is assumed that at least $13 \%$ (Jiskoot and others, 1998) and up to $90 \%$ (Liestøl, 1988) of these glaciers are of the surge type. Recently it has been suggested that some Svalbard glaciers, with known surges in the past, are no longer building up to new surges (Dowdeswell and others, 1995). This is supposed to be a result of climate warming in the Arctic, after the termination of the Little Ice Age about 100 years ago.

This paper investigates whether or not Hessbreen is building up towards a new surge. We also take a brief look at what the present glacier dynamics can indicate about the initiation processes of the last surge, as well as presenting new data from this surge. We will focus on the quiescent phase of Hessbreen, and the transition from the quiescent state to the surge state.

\section{FIELD AREA}

Hessbreen is a small valley glacier in southern Spitsbergen $\left(77^{\circ} 30^{\prime} \mathrm{N}, 15^{\circ} 06^{\prime} \mathrm{E}\right)$, situated a few kilometres west of the larger Finsterwalderbreen (Fig. 1). Hamberg (1905) first mapped the area in 1898. Since then, several aerial photographs (1936, 1956, 1969, 1970, 1990, 1995) at scales of $1: 17000$ to $1: 50000$ that cover parts of the glacier have been taken for the Norwegian Polar Institute. The glacier is now about $5 \mathrm{~km}$ long and terminates at a large push moraine. The accumulation area is up to $2.25 \mathrm{~km}$ wide, but the glacier narrows sharply to $<1 \mathrm{~km}$ below $300 \mathrm{~m}$ a.s.l. Hessbreen faces northeast and is surrounded by high mountains. The upper area is divided into basins by a nunatak, and the equilibrium-line altitude (ELA) is assumed to be at 330 ma.s.I. (Hagen and others, 1993). At present, crevasses are almost absent except for some small areas close to the nunatak and in the transition to ice aprons. Comparison of air photos from 1936 and 1956 shows that the degree of crevassing then and now is quite similar. The

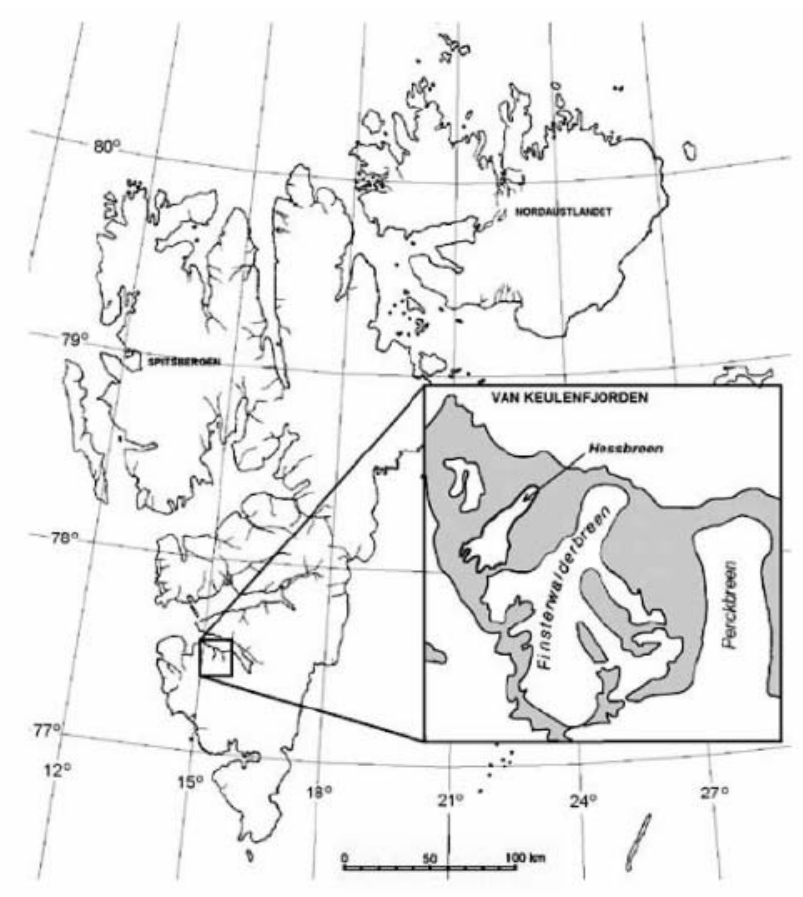

Fig. 1. Location map of Svalbard with insert of Hessbreen/Finsterwalderbreen. 


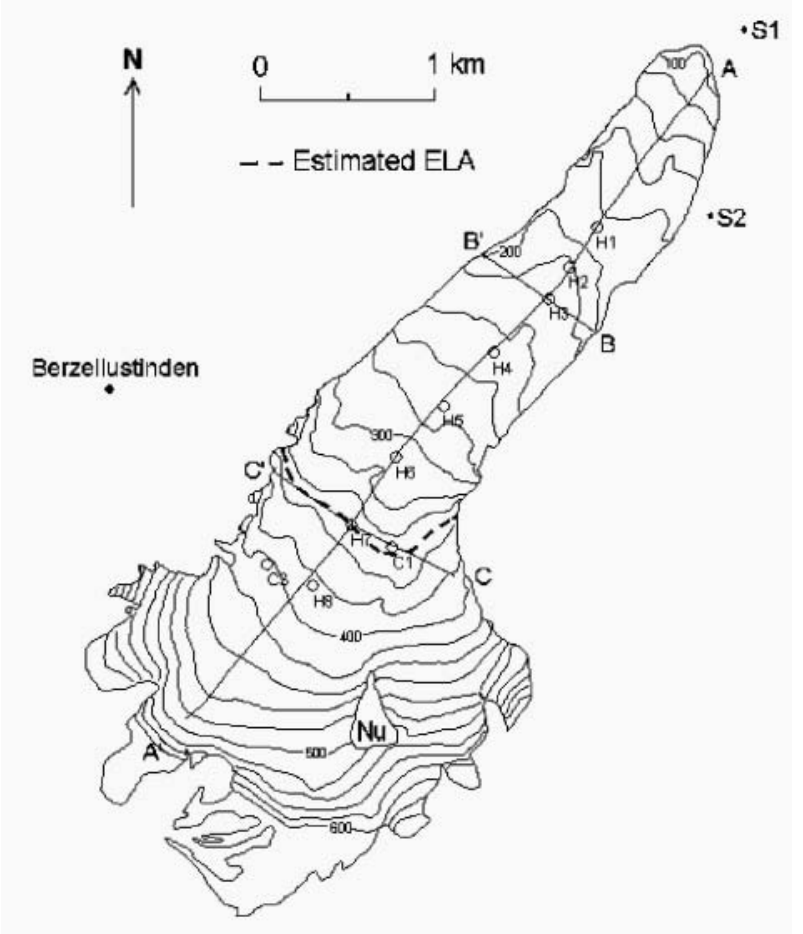

Fig. 2. Location of stakes $\mathrm{H} 1-\mathrm{H} 8, \mathrm{C} 1$ and $\mathrm{C} 3$, reference points $\mathrm{S} 1$ and S2, RES profiles $A-A^{\prime}, B-B^{\prime}$ and $C-C^{\prime}$ and estimated ELA $(350 \mathrm{~m})$. Based on map by A. J. Fox (unpublished data). Elevation contours in ma.s.l. with $20 \mathrm{~m}$ intervals. $\mathrm{Nu}$ is a nunatak.

area considered here is $5.1 \mathrm{~km}^{2}$, which covers Hessbreen up to $600 \mathrm{~m}$ a.s.l., although there are ice aprons extending along the back wall to an elevation of $950 \mathrm{~m}$ a.s.l.

Hessbreen is classified as a polythermal glacier by Liestøl (1976), based on the existence of water drainage during wintertime and temperature measurements. The glacier is known to have surged during 1972-76 (Liestøl, 1976; Dowdeswell and others, 1991) and probably also surged just before 1900, as in 1898 the glacier front was against the outermost moraine (Hamberg, 1905). The bedrock in the area consists of soft sedimentary rocks (Dallmann and others, 1990; Hjelle, 1993). Such conditions are considered, by some glaciologists, to be relevant to surges (e.g. Clarke and others, 1984; Jiskoot and others, 1998).

\section{METHODS}

\section{Radio-echo soundings}

Multi-frequency radio-echo sounding (RES) data were collected along the centre line and two cross-sections in spring 1995 (Fig. 2). The time-gated synthetic pulse radar system is described in Hamran and others (1995), and measurements conducted at Finsterwalderbreen at the same time and with the same equipment are discussed thoroughly in Ødegård and others (1997). Along the centre line, both $30-80 \mathrm{MHz}$ end-fed broad-bandwidth dipole antennae and $320-370 \mathrm{MHz}$ six-element Yagi antennae were used. For cross-sections $B-B^{\prime}$ and $C-C^{\prime}$ (Fig. 2), only $30-80 \mathrm{MHz}$ were used. $C-C^{\prime}$ is close to the ELA cross-section which is used for the balance-flux calculation. The radio-echo soundings are combined with the elevation contours based on aerial photos from 1990 (unpublished map from A. J. Fox, 1995).
Table 1. Surveying sessions of Hessbreen and their corresponding dates

\begin{tabular}{lll}
\hline Winter/spring & Summer 1 & Summer 2 \\
\hline & 1-95: 9-10 Aug. 1995 & 2-95: 20-21 Aug. 1995 \\
& & 3-96: 7 Aug. 1996 \\
1-96: 23 Apr. 1996 & 2-96: 17 July 1996 & \\
1-97: 27 Apr. 1997 & &
\end{tabular}

The radio-echo soundings were carried out 5 years after the aerial photography, but no significant change in the glacier surface in this period is assumed.

\section{Surveying}

The surveying was based on ten stakes (Fig. 2). During spring 1994, two velocity stakes, $\mathrm{H} 2$ and $\mathrm{H} 6$, were installed on the centre line of the glacier. This line was supplemented with six more stakes in summer 1995. The total length of this transect was about $2.5 \mathrm{~km}$. Two more stakes, C1 and C3, were added east and west respectively of the two uppermost stakes. These stakes were meant to form a transect with $\mathrm{H} 7$ in the centre, but C3 had to be moved due to the large amount of rocks being incorporated into the ice below the mountain, Berzeliustinden (Fig. 2). Two reference points, S1 and S2 (Fig. 2), were established on the end moraine and a hill east of the glacier. Both sites were vegetated and it was assumed that the points were sufficiently stable for this relatively short period of survey. A cairn on the island Eholmen, about $9.8 \mathrm{~km}$ northwest of the end moraine, was used as a reference target in the surveying. The stakes were surveyed using a theodolite (Wild T2) and an EDM (Wild Di3000), most being observed from both fixed points S1 and S2. The measurements were made six times between summer 1995 and spring 1997, and dates are listed in Table 1. Due to fog, it was impossible to measure all stakes during each survey.

\section{Mass balance}

The winter balance was measured along the stake profile. Due to a lack of stakes, the coverage above the ELA was poor (Fig. 2). As a supplement to the Hessbreen measurements, the results were compared with data from Finsterwalderbreen (Fig. 3), which has an intermittent mass-balance series from 1950 (Liestøl, 1976; Nuttall and others, 1997). Over the last 50 years, there has been no significant trend in the total net mass-balance data. The mass-balance data of Finsterwalderbreen have been applied to Hessbreen.

\section{Basal shear stress and dynamic balance}

The basal shear stress $\tau$ is given by

$$
\tau=f \rho g h \sin \alpha
$$

(Nye, 1965), where $\rho$ is the density of ice, $g$ the gravitational constant, $h$ the ice thickness and $\alpha$ the surface slope. Nye introduced the shape factor $f$ to give a more realistic estimate of the shear stress in valley glaciers. $f$ is a dimensionless parameter that varies with the geometry of the glacier. The difference between the balance and the dynamic fluxes at a given horizontal location $x$ along the glacier gives the rate of mass increase above $x$.

$$
\frac{\mathrm{d} M(x)}{\mathrm{d} t}=Q_{\mathrm{b}}(x)-Q_{\mathrm{v}}(x)
$$

where $M(x)$ is the mass above the position $x, Q_{b}(x)$ is the 
balance flux across the section and $Q_{v}(x)$ the volume flux or the actual flux across the section (e.g. Raymond, 1980). Here $Q_{b}$ is approximated as

$$
Q_{\mathrm{b}}=A b,
$$

where $A$ is the upstream area of the section $x$, and $b$ is the average net balance in this area. The volume flux $Q_{v}$ is here approximated by:

$$
Q_{v}=\hat{u} S,
$$

where $\hat{u}$ is the annual surface velocity in the middle of the section and $S$ the area of the section.

\section{RESULTS AND INTERPRETATION}

\section{Thermal regime and influence on the drainage pattern}

The RES shows the interface between cold and temperate ice up to about $4 \mathrm{~km}$ up-glacier from the terminus. This assumption is made from interpretation of radio-echo measurements with the same equipment as on Finsterwalderbreen (Hamran and others, 1995) and other Svalbard glaciers (Björnsson and others, 1996). However, reflections from the bed could be followed only $2.5 \mathrm{~km}$ up-glacier (Fig. 4c). Interpretation of the longitudinal transect is shown in Figure 5, and suggests that the glacier is at the pressuremelting point over most of the bed along the centre line, with the exception of the lower $\sim 600 \mathrm{~m}$. The first few hundred metres of the $320-370 \mathrm{MHz}$ profile (Fig. $4 \mathrm{~d}$ ) did not agree with the $30-80 \mathrm{MHz}$ profile (Fig. 4c), probably due to englacial material in this area.

As few crevasses are present, glacier meltwater drains mainly supraglacially in a network, with the channels developing in the central part of the glacier. In the lower part, the main channels end in moulins. In the 1995 photos the pattern and location of several of the channels were similar to those appearing in the 1956 photos. Icing in front of the glacier was observed during this study and could also be seen on the air photos.

\section{Flow velocities}

The survey data were calculated as stake coordinates using a least-squares solution with both direction and distance measurements. The accuracy, given as standard deviation of the stakes coordinates, was \pm 0.03 to $\pm 0.1 \mathrm{~m}$. This is rather high, but not unexpected due to the often difficult observation conditions. Direction measurements are more influenced by difficult conditions than distances, and the velocity results have been based on distance measurements only. The direct distance measurements from the fixed point S1, which are more or less exactly in line with the glacier flow, were used to calculate stake velocities, except for stakes $\mathrm{H} 4$ and $\mathrm{H} 5$ where distances measured from the fixed point S2 were used. From S2 these distance measurements have angles to the flowline of approximately $17^{\circ}$ and $21^{\circ}$, which have been taken into account. Velocities from the direct distance measurements correspond well (most within $10 \%$ ) with velocities computed from the adjusted coordinates. The surface velocities along the centre line and crossprofile are shown in Figure 6 and Table 2. The vectors of ice movement are shown in Figure 7.

The annual velocities are calculated for the period 2-95 to 3-96 (349 days; see Table 1). The interval between 2-95 and 1-96 forms the basis of the winter velocities ( 245 days). For some of the stakes, winter velocities can also be computed

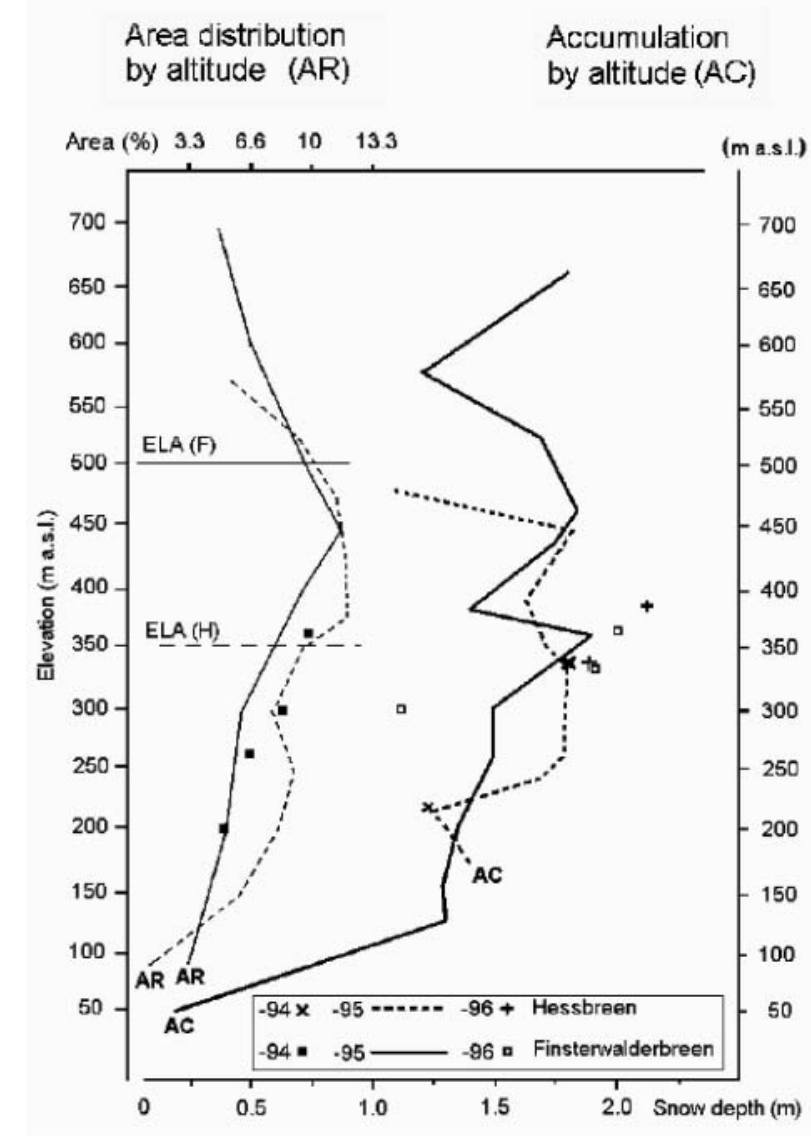

Fig. 3. Left scale: area distributions of Hessbreen and Finsterwalderbreen. Right scale: observed winter snow depth for 1994, 1995 and 1996. The data for 1994 and 1996 are sparse and shown only as points.

for the period 2-96 to 1-97 (263 days), but due to melting out and tilting of some stakes these results have not been used except to verify the listed results. The two winter velocities coincide within $\pm 0.1 \mathrm{~m} \mathrm{a}^{-1}$ for stakes $\mathrm{H} 1-\mathrm{H} 3$, and $\pm 0.2 \mathrm{~m} \mathrm{a}^{-1}$ for stakes $\mathrm{H} 6-\mathrm{H} 8$. The summer velocities can be calculated between 1-95 and 2-95 (11 days), or 2-96 and 3-96 (20 days), but measurements are not available for all stakes in both the periods. The time-spans are very short and the estimated standard deviations of the velocity vectors are as high as or even higher than the velocities found for the slowest-moving stakes. The summer velocities of stakes $\mathrm{H} 1-\mathrm{H} 5$ have thus been computed as the combined spring/summer velocity in 1996 (1-96 to 3-96), as there was no significant difference between the spring and summer velocities for these stakes. The velocities and their corresponding standard deviations are listed in Table 2. For all stakes, the annual velocities were close to their winter velocities, which were $71-95 \%$ of the annual velocity. The increased summer velocities can only last for 1-3 months to achieve the observed annual velocities. The largest seasonal variation was found at stake $\mathrm{H} 6$, where the summer velocity was 2.6 times the winter velocity. The velocities probably fluctuate during the spring/summer season, with velocities both higher and lower than the estimated averages of this season.

\section{Basal shear stress}

The RES profiles (Fig. 4a and b) confirm the assumption that the cross-profile approximates a semi-ellipsoid. Values of 


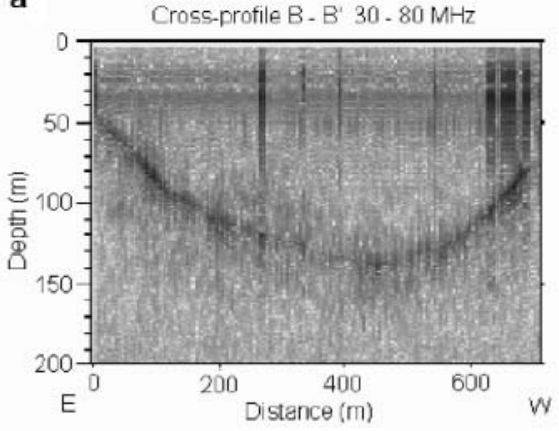

b

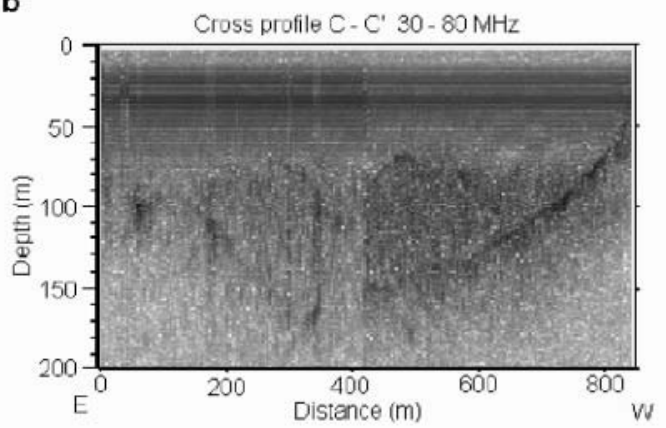

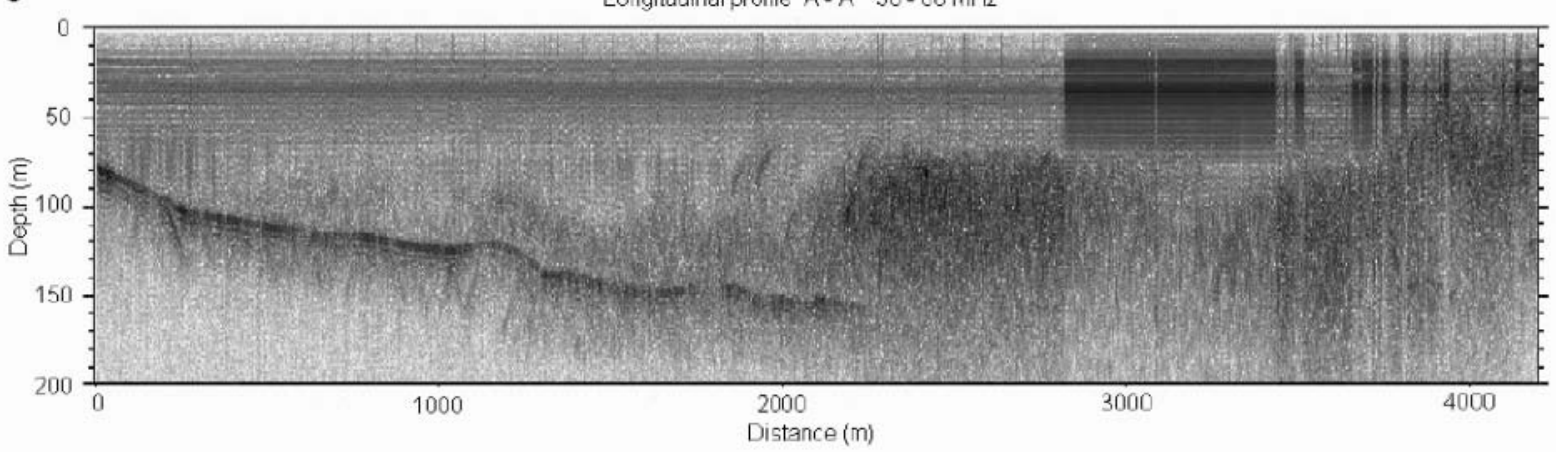

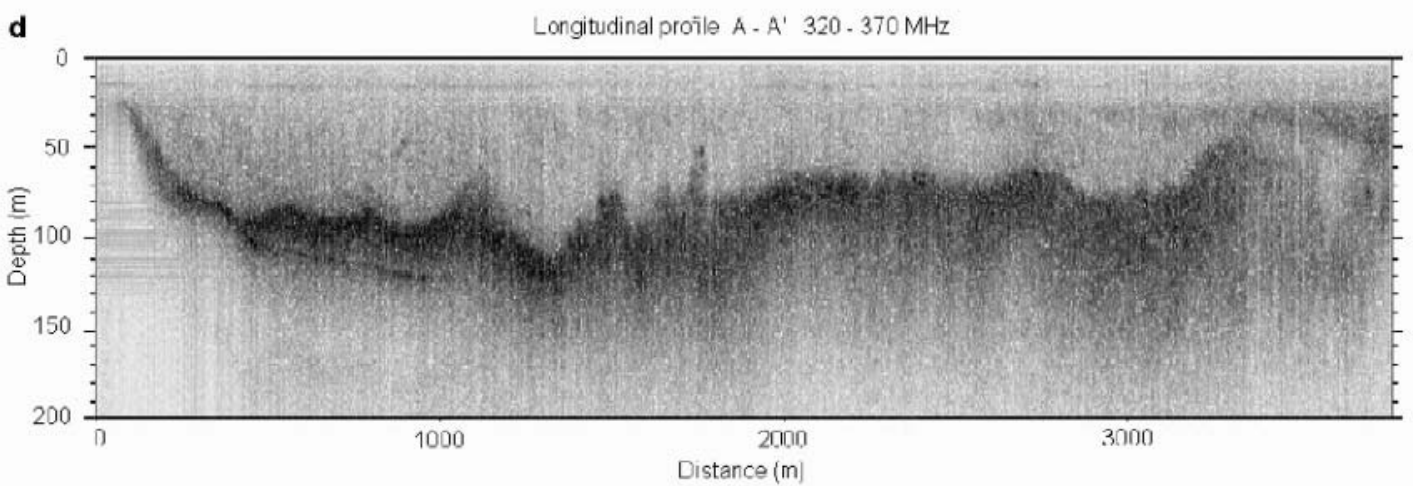

Fig. 4. RES profile images. Cross sections $B-B^{\prime}(a)$ and $C-C^{\prime}$ (b) and longitudinal profile (c) show the ice depth, and longitudinal profile (d) indicates the thickness of the cold surface layer. The longitudinal profiles start about $300 \mathrm{~m}$ from the glacier front.

the shape factor $f$ for semi-ellipsoidal profiles (Nye, 1965) vary between 0.80 and 0.84 (Table 3 ). The surface slopes were calculated by averaging over 8-10 times the average ice thickness at each stake (Meier and others, 1974), and vary between $4.2^{\circ}$ and $6.2^{\circ}$. The basal shear stress $\tau$ (Equation (1)) was calculated from measured elevation profiles and $f$ values. $\tau$ was highest at stake $\mathrm{H} 7$, with a maximum value of $99 \mathrm{kPa}$, decreasing to a minimum of $65 \mathrm{kPa}$ at stake $\mathrm{H} 4$, and increasing again at stake $\mathrm{H} 3$.

\section{Mass balance}

The net mass-balance results from 1994 to 1996 (Table 4), which had warmer than average summers, showed the ELA of Hessbreen to be approximately $400 \mathrm{~m}$ a.s.l. Hambrey and Dowdeswell (1997) also found the limit of superimposed ice in 1995 to be at about 400 m a.s.l. The ELA of Finsterwalderbreen in these years was found to be at 500 ma.s.l. (Nuttall and others, 1997), about $100 \mathrm{~m}$ higher than the 50 year average (Hagen and others, 1993). The mass balance is stable in this area, and generally correlates well with the ELA (e.g. Young, 1981; Hagen and Liestøl, 1990). The ELA at Hessbreen has been estimated before at $330 \mathrm{~m}$ a.s.I. (Hagen and others, 1993), based upon stake measurements from the 1970s and related to the ELA at Finsterwalderbreen (personal communication from O. Liestøl, 1999). It is thus assumed that the average ELA at Hessbreen is no higher than $350 \mathrm{~m}$ a.s.l. (Fig. 2) and probably slightly lower.

The comparison between the mass balances of Hessbreen and Finsterwalderbreen (Fig. 3) shows slightly higher accumulation on Hessbreen, which could be due to local topography. The more shaded location of Hessbreen could account for there being less ablation, and accumulation from avalanches is probably more important for the mass balance of the small Hessbreen than for the larger Finsterwalderbreen. Other investigations have shown that superimposed ice is common on Svalbard glaciers (Liestøl, 1974), and on Finsterwalderbreen this represents a significant portion of the total accumulation (Ødegård and others, 1997; Pinglot and others, 1997) which is also true for Hessbreen. The water equivalent data for Finsterwalderbreen (Nuttall and others, 1997) are used in the calculations for Hessbreen, assuming that this will give slightly lower values than the actual situation on Hessbreen. If a build-up situation is found with these lower mass-balance values, it will strengthen the probability of an actual build-up on Hessbreen. 


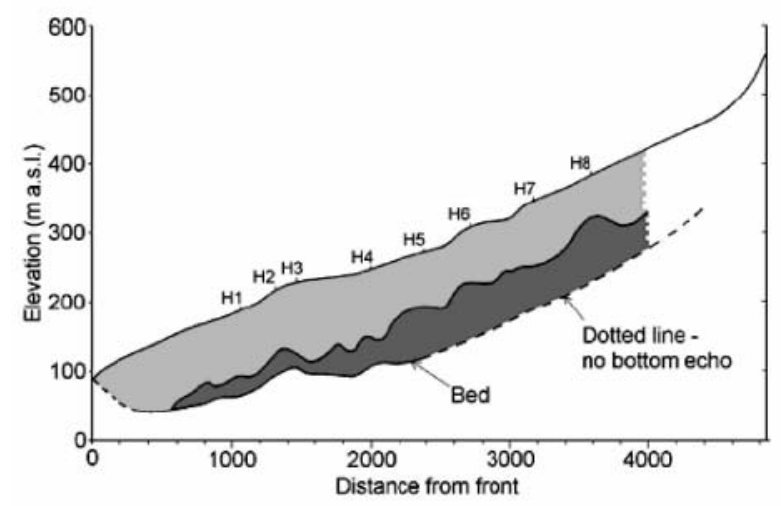

Fig. 5. Interpretation of the radio-echo profiles. Light raster indicates cold ice, darker raster temperate ice. Surface profile drawn from map (A. J. Fox, unpublished data). Surveying stakes $\mathrm{H} 1-\mathrm{H} 8$ are marked. Missing data near the front and lack of bottom echo are drawn with dotted line.

\section{Surge history}

Liestøl (1976) assumed that the last surge of Hessbreen started between 1972 and 1974. However, aerial photos from late August 1969 (NP S69 2905-2908 and S69 29652967, approximate scale $1: 17$ 000) show long, transverse, crescent-shaped crevasses in the upper part of the glacier and down to about $300 \mathrm{~m}$ a.s.l., and also lateral crevasses further down along the eastern side (Fig. 8). These are not visible on other aerial photos, except on those from 1970 (scale 1:50000), and are not described earlier. Liestøl reported no visible crevasses on a visit to the glacier at 520 m a.s.l. in early summer 1968 (personal communication from O. Liestøl, 1999), which suggests that the surge was initiated between Liestøl's visit and the aerial photography, i.e. between the summers of 1968 and 1969. As no crevassing was observed towards the snout of the glacier during a survey of the lower part in 1972, there was a delay before the surge became fully developed.

\section{DISCUSSION}

\section{Thermal regime and drainage}

In small or narrow polythermal glaciers the glacier bed is cold and the glacier is frozen to the bedrock (Björnsson and others, 1996). A 'cold ring thermal regime', with cold, 'dry'

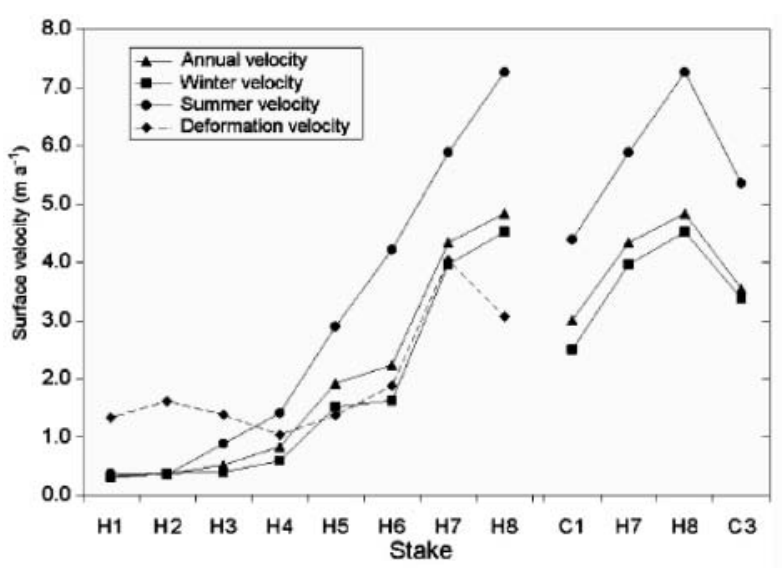

Fig. 6. Surface velocities at stakes: annual, winter and summer.

ice uppermost and surrounding temperate, 'wet' ice in the inner zones, is found in several glaciers on Svalbard (e.g. Schytt, 1969; Kotlyakov and Macheret, 1987). From the RES data only, it is difficult to determine whether the low velocities at the snout are caused by cold ice throughout or if temperate ice in the centre is strongly influenced by cold marginal ice. Ice velocities in the narrow part of the glacier show a fall instead of the expected increase. The decrease in velocity from the upper to the lower stakes can partly be explained by the decrease in ice thickness. The shape of structures from former crevasses (aerial photos NP S95 1121-1123), and avalanche patterns on the glacier surface indicate the presence of cold marginal ice. Whilst the crevasse traces are straight and parallel in the upper-middle part, those further downstream near the glacier terminus have a sharp, convex down-glacier profile. This study suggests that Hessbreen has a temperate zone only at the bed in the centre of the accumulation area, and along the centre line below the ELA. Björnsson and others (1996) studied midre Lovénbreen, Svalbard, which has geometry like Hessbreen, and found a similar temperature regime for this glacier. Blatter (1987) suggested a similar pattern for a Canadian glacier, where he found indications of a $300 \mathrm{~m}$ wide temperate centre line. The cold margins possibly control the velocity pattern of Hessbreen.

The present-day main supraglacial drainage channels seem to have reverted to the pre-surge supraglacial drainage paths. This is supported by the similar velocities at the snout found before the surge (Liestøl, 1976), and indicates a stable

Table 2. Measured velocities and corresponding standard deviations (sdev) of stakes. Annual (A), winter (W) and spring/summer or summer velocities $(\mathrm{S})$ and their standard deviations. Units are $\mathrm{ma}^{-1}$

\begin{tabular}{|c|c|c|c|c|c|c|}
\hline Stake & A & A sdev & W & W sdev & $S$ & S sdev \\
\hline $\mathrm{H} 1$ & 0.33 & 0.02 & 0.30 & 0.03 & 0.38 & 0.07 \\
\hline $\mathrm{H} 2$ & 0.37 & 0.02 & 0.37 & 0.03 & 0.36 & 0.08 \\
\hline $\mathrm{H} 3$ & 0.52 & 0.02 & 0.40 & 0.03 & 0.89 & 0.09 \\
\hline $\mathrm{H} 4$ & 0.84 & 0.03 & 0.59 & 0.04 & 1.41 & 0.10 \\
\hline $\mathrm{H} 5$ & 1.92 & 0.03 & 1.51 & 0.04 & 2.89 & 0.12 \\
\hline $\mathrm{H} 7$ & 4.33 & 0.03 & 3.96 & 0.05 & 5.88 & 1.10 \\
\hline H8 & 4.83 & 0.04 & 4.52 & 0.05 & 7.26 & 1.16 \\
\hline $\mathrm{C} 1$ & 3.00 & 0.03 & 2.50 & 0.05 & 4.39 & 1.10 \\
\hline $\mathrm{C} 3$ & 3.54 & 0.04 & 3.38 & 0.05 & 5.35 & 1.16 \\
\hline
\end{tabular}




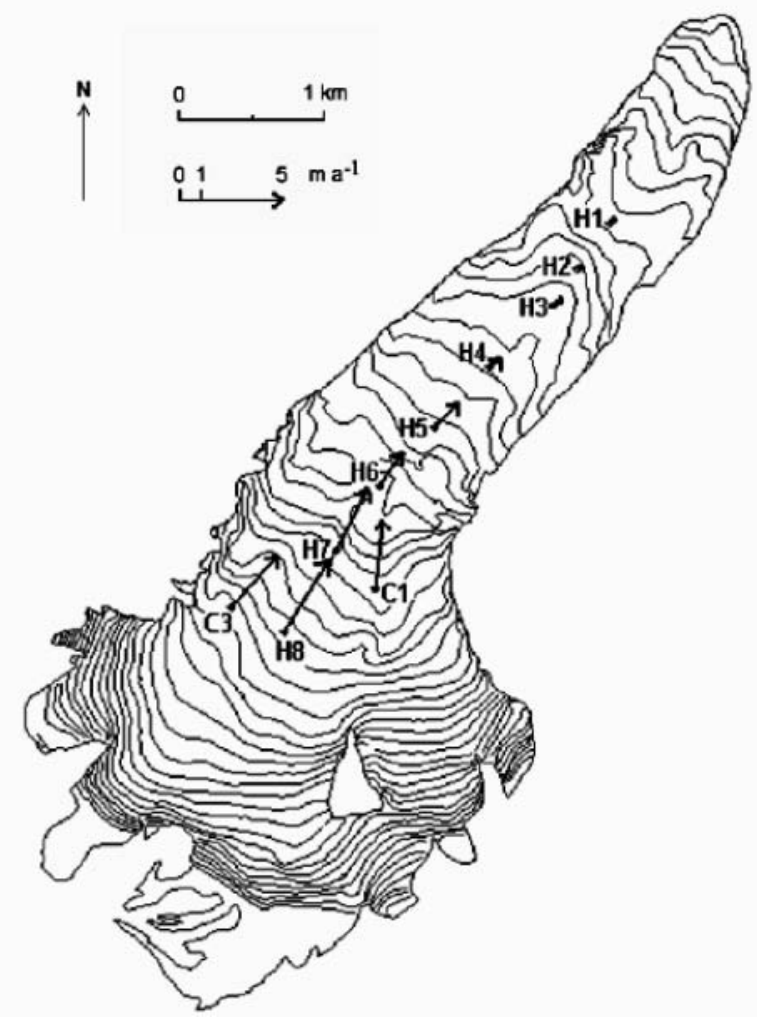

Fig. 7. Velocity and direction of ice movement at stakes (annual mean values).

situation during the quiescent phase. However, the seasonal variations in velocity, the temperate ice found by the RES and the occurrence of icing in front of the glacier indicate subglacial drainage is present. A substantial increase in the velocity during spring at stake $\mathrm{H} 6$, where the glacier narrows, indicates that the channels are rather small. In autumn the water passages contract, and larger amounts of surface meltwater increase the water pressure during spring (Iken and others, 1983; Gudmundsson and others, 2000). A well-developed basal drainage system beneath Finsterwalderbreen was found to explain the increase in surface velocities during the melt season (Nuttall and others, 1997), also suggesting the existence of a developed drainage system beneath parts of Hessbreen.

\section{Flow velocities}

Velocities are generally low on small glaciers on Svalbard (Hagen and others, 1993). Austre Brøggerbreen had a measured maximum velocity of $2 \mathrm{~m} \mathrm{a}^{-1}$, while for midre Lovénbreen it was $4.5 \mathrm{~m} \mathrm{a}^{-1}$ (Liestøl, 1988). Accelerated summer velocities, as measured on Hessbreen, are a wellknown phenomenon in polythermal glaciers (e.g. Hooke and others, 1989; Rabus and Echelmeyer, 1997; Melvold and Hagen, 1998). The pattern of seasonal variations, larger in the central part of Hessbreen and less at the terminus and the head, was quite similar to that found at Finsterwalderbreen (Nuttall and others, 1997). However, there are differences between summer and winter velocities along the entire glacier at Finsterwalderbreen, while there are no measurable seasonal differences at the snout of Hessbreen. The low velocities are of the same magnitude as those found at the same ice thickness on the cold glacier Scott Turnerbreen,

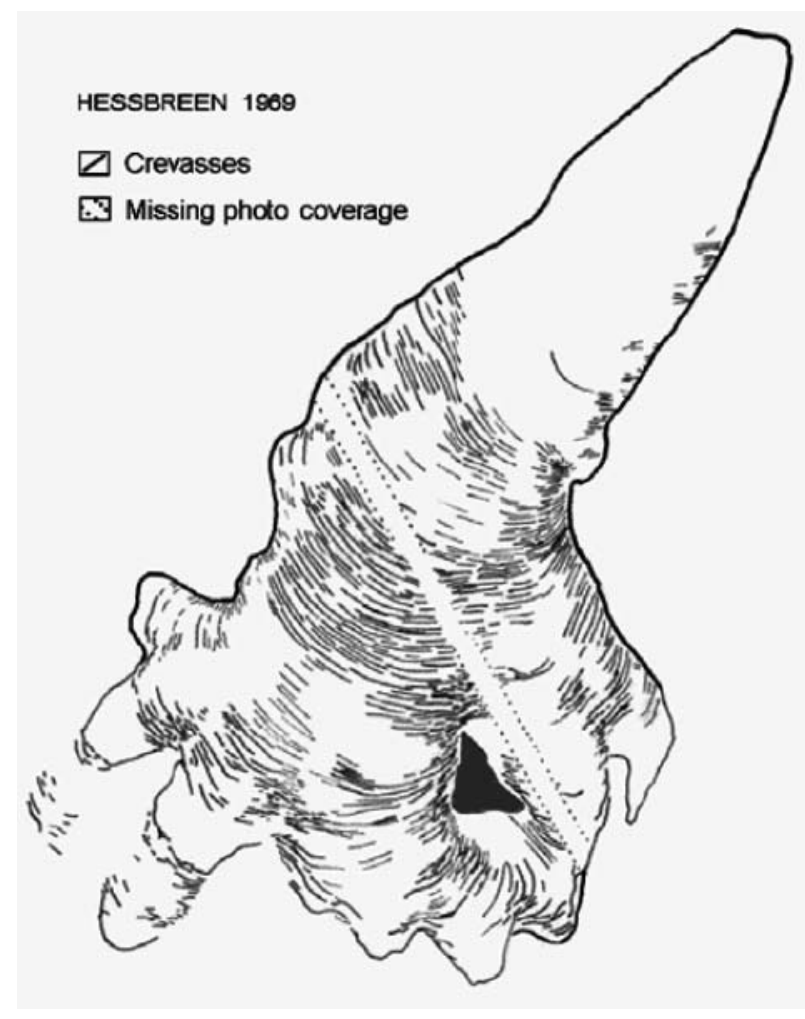

Fig. 8. Crevasse pattern from aerial photos NP S69 2905-2908 and S69 2965-2967. The crevasses outside the outline indicate crevassing in the ice aprons. Note: figure has incorrect map geometry.

Svalbard (Hodgkins, 1994), which supports the suggestion that the tongue of Hessbreen is frozen to the bed.

\section{Basal shear stress}

The basal shear stress in a temperate valley glacier is usually 50-200 kPa (Nye, 1952; Budd and others, 1979). In surging glaciers the basal shear stresses are often larger, especially in the last phase of the build-up period. Bjuvbreen, Svalbard, was found to have a value of $170 \mathrm{kPa}$ (Hamilton, 1992), and for Usherbreen, Svalbard, the mean value was calculated as $61 \mathrm{kPa}$ just before a surge and $33 \mathrm{kPa}$ after the surge (Hagen, 1987). The variations in basal shear stresses along the centre line on Hessbreen, between 65 and $99 \mathrm{kPa}$, are within the normal range for Svalbard surging glaciers in their build-up phases.

\section{Balance flux and volume flux}

The cross-sectional area at the ELA, for which the balance flux and volume flux were calculated, is obtained from the maximum depth from the $\mathrm{C}-\mathrm{C}^{\prime}$ profile assuming a semiellipsoidal profile. The $350 \mathrm{~m}$ contour line coincides roughly with the radar profile $\mathrm{C}-\mathrm{C}^{\prime}$ (Fig. 2). Where the contour line does not follow the radar profile, the ice thickness is extrapolated. The cross-sectional area of the glacier at $350 \mathrm{~m}$ a.s.I. was calculated to be $0.12 \mathrm{~km}^{2}$.

The balance flux $Q_{b}$ (Equation (3)) was calculated using the mass balance, $2.78 \times 10^{-4} \mathrm{~km} \mathrm{a}^{-1}$ w.e. above the ELA, found at Finsterwalderbreen (Nuttall and others, 1997), multiplied by the accumulation area obtained from the area distribution curve (Fig. 3), $2.81 \mathrm{~km}^{2}$. Assuming an ice density of $900 \mathrm{~kg} \mathrm{~m}^{-3}, Q_{\mathrm{b}}$ is $8.68 \times 10^{-4} \mathrm{~km}^{3} \mathrm{a}^{-1}$ of ice. Thus the averaged velocity through the cross-section needed to 
Table 3. Values used for calculation of basal shear stress $\tau$. $w$ is the half-width, $h$ the centre-line depth, $f$ the shape factor and $\alpha$ the surface slope

\begin{tabular}{llllll}
\hline Stake & $w$ & $h$ & $f$ & $\alpha$ & $\tau$ \\
& & & & & \\
& $\mathrm{m}$ & $\mathrm{m}$ & & & $\mathrm{kPa}$ \\
\hline $\mathrm{H} 1$ & 300 & 100 & 0.80 & 6.2 & 75.2 \\
$\mathrm{H} 2$ & 315 & 105 & 0.80 & 6.2 & 78.9 \\
$\mathrm{H} 3$ & 330 & 100 & 0.83 & 6.2 & 78.0 \\
$\mathrm{H} 4$ & 400 & 125 & 0.82 & 4.2 & 65.3 \\
$\mathrm{H} 5$ & 410 & 135 & 0.80 & 4.2 & 68.8 \\
$\mathrm{H} 6$ & 460 & 145 & 0.82 & 4.2 & 75.8 \\
$\mathrm{H} 7$ & 500 & 145 & 0.83 & 5.4 & 98.5 \\
$\mathrm{H} 8$ & 525 & 135 & 0.84 & 5.4 & 93.0 \\
$\mathrm{C} 1$ & & 110 & 0.83 & 5.4 & 74.2 \\
$\mathrm{C} 3$ & & 80 & 0.84 & 5.4 & 55.0 \\
\hline
\end{tabular}

maintain the equilibrium is $7.2 \mathrm{~m} \mathrm{a}^{-1}$. The annual surface velocity measured at stake $\mathrm{H} 7$ gives $4.3 \mathrm{~m} \mathrm{a}^{-1}$, which gives a maximum ice volume flux $Q_{v}$ (Equation (4)) of $5.16 \times 10^{-4} \mathrm{~km}^{3} \mathrm{a}^{-1}$. Hence it appears that the actual flux is no more than about $60 \%$ of the balance flux at present.

It is difficult to give reliable error estimates for some of the values used; but calculations were performed using estimates to give the larger mass balance or the smaller volume flux. The following points indicate the possible errors and their effects on estimates.

1. The mass-balance data (mw.e.) were lower than can actually be expected on Hessbreen. If the actual mass balance is larger than that used, as is likely, then it is even more possible that Hessbreen is building up to a surge state. A $10 \%$ higher mass-balance value will reduce the actual balance-flux ratio from $60 \%$ to $54 \%$.

2. The accumulation area does not include parts of the ice aprons (see Fig. 2). This area is difficult to determine exactly, but is approximately $0.5 \mathrm{~km}^{2}$, and will contribute to the positive mass balance.

3. If the cross-sectional area under the ELA is smaller than calculated using a curved ELA, $Q_{v}$ becomes smaller. If the area under the curved ELA is about $10 \%$ larger than for a straight ELA, this gives a $10 \%$ increase in $Q_{v}$.

4. The mean surface velocity at the centre line (stake H7) overestimates the actual velocity across the ELA crossprofile. Considering the effects of cold marginal ice, and reduced velocity toward the margins and with depth, the actual volume flux $Q_{v}$ will be about $25 \%$ lower than computed above.

Even though there are uncertainties in both the balance-flux and the volume-flux values, it is clear that the glacier at present transports a smaller volume of ice than required to maintain a stable ice-surface profile. Since the uncertainties are estimated in such a way that they favour a smaller balance flux and a higher volume flux, the build-up could be larger than calculated. This shows that the glacier is building up in the accumulation area. Present build-up situations are also found in two other Svalbard glaciers, Finsterwalderbreen (Nuttall and others, 1997) and Kongsvegen (Melvold
Table 4. Net mass balance for Finsterwalderbreen $(\mathrm{F})$ and Hessbreen (H), 1995 and 1996

\begin{tabular}{|c|c|c|c|c|}
\hline Elevation & $\mathrm{H}-95$ & $\mathrm{H}-96$ & F-95 & F-96 \\
\hline ma.s.l. & m.w.e. & mw.e. & mw.e. & m w.e. \\
\hline 387 & & 0.00 & & -0.15 \\
\hline 365 & & & -1.19 & -0.39 \\
\hline 340 & -0.47 & -0.08 & & \\
\hline 303 & & & -1.31 & \\
\hline
\end{tabular}

and Hagen, 1998), although these are much larger glaciers than Hessbreen.

\section{Surge behaviour}

On several glaciers, a surge has been characterized by a surge wave propagating down the glacier (e.g. Echelmeyer and others, 1987; Clarke and Blake, 1991; Lawson, 1997). Echelmeyer and others (1987) studied the chaotic crevasse pattern on Peters Glacier, Alaska, USA, where a surge wave caused both longitudinal and transverse crevasses. No such crevasse pattern was identified on photos from the surge of Hessbreen, and there is no apparent bulge in the geometric profile from 1970 (Liestøl, 1976). Neither was a bulge found on Osbornebreen, Svalbard, during a surge (Rolstad and others, 1997). Compressive flow was found during a surge on Trapridge Glacier, Yukon Territory, Canada (Clarke and Blake, 1991), without resulting in visible crevasses. Theoretically this also could have been the situation on Hessbreen. However, the 1990 geometric profile in this study shows smaller bulges (Fig. 5) are present on Hessbreen and could be a part of the build-up pattern. The small bulges seem to be generated in the area around stake $\mathrm{H} 6$ and are probably caused by deceleration in this area, as the velocities are considerably lower than further upstream, where basal sliding during winter is also present. This process can also contribute to more rapid closure of the water channels in this area.

One of the most fundamental, spatial properties of a surge is the location on the glacier at which surge motion is initiated (Lawson, 1997). Based on observations after the surge, Liestøl (1976) suggested it started at the snout. Photos taken in 1974 show that the upper part was entirely crevassed by wide transverse crevasses when the surge finally spread over the whole glacier. At the same time the lower part of the glacier moved like a solid block with few surface changes. The 1969 aerial photos show a crevasse pattern that agrees with Nye's (1952) description of a combination of extending flow and the assumption that the ice is frozen to the ground laterally. The described crevasse pattern at the initiation of and during the surge on Hessbreen could be a result of extensive flow where the glacier narrows, indicating that the surge started here. The lateral crevasses further down are probably a response to mass movement. Although the conditions may not have been the same as they are now, the shape of the glacier favours conditions for a colder snout that could behave as a dam to the ice upstream, from the wider accumulation area. McMeeking and Johnson (1986) argue that a surge may be initiated by a discontinuity of motion in a segment of the glacier. If this is true for Hessbreen, this segment probably 
developed in the area where stake $\mathrm{H} 6$ is situated, as there are indications of large variations in velocities here, and the lowermost transverse crevassing ends here. Such effects can be due to excess water in the drainage system, occurring in small local areas (Björnsson, 1998). Increased velocity in the initiation area destabilized the upper part, while the lower part was probably frozen to the ground, making it more stable. These changes result in increased fracturing of the glacier surface, which leads to even more rapid drainage of surface meltwater through the crevasses, further increasing velocities. Osbornebreen experienced several summer seasons where the surface drainage changed substantially, which may have been significant to the block motion during the surge (Rolstad and others, 1997). This is probably an important process on Hessbreen as well.

Schytt (1969) assumed the described polythermal regime is an important factor in glacier surges, which is also shown in a study by Jiskoot and others (2000). A causal relationship between keyhole-shaped glaciers and surging has been suggested for Svalbard, but no significant verification for the hypothesis has yet been found. However, this study suggests that cold marginal ice, which is most extensive in the lower part due to the shape of the glacier, is an important factor in the build-up pattern of this glacier. Characteristics of the subglacial drainage system are thought to be important to the surge mechanism (Kamb and others, 1985). The seasonal variation in velocity in the area around $\mathrm{H} 6$ is probably an effect of the drainage system in this section. If the conditions were similar before the surge, this could have been significant to the initiation of the surge. Hubbard and others (1998) found that an area of inferred subglacial channels was probably exposed to strong decoupling for some time. Under certain conditions the water can be blocked by stagnant ice or slow glacier motion (Robin, 1986). When the water was released in the next phase the conditions for surge were present.

The results of this study indicate that there was a slow development of the surge on Hessbreen, starting about 1969 but not developing fully until 1972. On Fridtjovbreen, the development of new crevasses was observed (personal communication from S. Onarheim, 1999) 2 years before large crevasses were seen in autumn 1995 (Glasser and others, 1998), when the surge is assumed to have started. This indicates that surge initiation on Svalbard could be a slow process developing over several years, in contrast to glaciers with a faster initiation (e.g. Alaskan surging glaciers (Harrison and others, 1994; Lawson, 1997)). It is also consistent with the observed long build-up period and long surge duration on Svalbard as suggested by other authors (Dowdeswell and others, 1991; Murray and others, 2000). Assuming surge initiation in 1972, Dowdeswell and others (1991) set the surge duration of Hessbreen to 5 years. The present data indicate that the surge of Hessbreen lasted for at least 8 years, and the quiescent phase for about 70 years. Hessbreen appears to be similar to other glaciers in Svalbard having a long active phase and long quiescent phase (Murray and others, 1997; Nuttall and others, 1997).

\section{CONCLUSIONS}

Comparison of the present balance flux with the measured volume flux shows that the glacier only transports about $50 \%$ of the mass gained in the accumulation area through the ELA. The velocity pattern of the glacier indicates that the sides are frozen to the ground. The shape of the glacier, with a wide accumulation area that narrows sharply toward the snout, probably affects the dynamics. Seasonal velocity variations are considerable where the glacier narrows, which indicates that the hydrology is also characterized by seasonal features.

Aerial photographs dating from 1969 show that the surge, which was formerly assumed to have started after 1972, actually started in 1969 . The crevasse pattern, with crescentshaped crevasses in the accumulation area, and none in the lower part of the glacier, indicates that the surge started in the area where the glacier narrows. This is the same area where the present distinct seasonal velocity variations are found.

\section{ACKNOWLEDGEMENTS}

We thank the late O. Liestøl for help with understanding aspects of the former studies of Hessbreen, S.-E. Hamran and J.O. Hagen for collecting the radar data, and A.-M. Nuttall for providing some of the mass-balance data. Several other people assisted in the field, and M. Jackson and J. Brittain improved the English. Reviews by P. Jansson, H. Jiskoot and an anonymous reviewer substantially improved the paper. We also thank the Scientific Editor R. Naruse, and R.S. Ødegård and K. Melvold for their comments. This work was supported through European Union grant EN5V-CT930299 and by the Department of Physical Geography, University of Oslo, and the University Courses on Svalbard.

\section{REFERENCES}

Björnsson, H. 1998. Hydrological characteristics of the drainage system beneath a surging glacier. Nature, 395(6704), 771-774.

Björnsson, H. and 6 others. 1996. The thermal regime of sub-polar glaciers mapped by multi-frequency radio-echo sounding. J. Glaciol., 42(140), 23-32.

Blatter, H. 1987. On the thermal regime of an Arctic valley glacier: a study of White Glacier, Axel Heiberg Island, N.W.T., Canada. J. Glaciol., 33(114), 200-211.

Budd, W.F., P.L. Keage and N.A. Blundy. 1979. Empirical studies of ice sliding. J. Glaciol., 23(89), 157-170.

Clarke, G.K.C. 1976. Thermal regulation of glacier surging. J. Glaciol., 16(74), 231-250.

Clarke, G.K.C. and E.W. Blake. 1991. Geometric and thermal evolution of a surge-type glacier in its quiescent state: Trapridge Glacier, Yukon Territory, Canada, 1969-89. J. Glaciol., 37(125), 158-169.

Clarke, G.K.C., S.G. Collins and D.E. Thompson. 1984. Flow, thermal structure, and subglacial conditions of a surge-type glacier. Can. J. Earth Sci., 21(2), 232-240.

Dallmann, W.K. and 7 others. 1990. Van Keulenfjorden, Temakart 15. (Scale $1: 100,000$.$) Oslo, Norsk Polarinstitutt. (Geological$ map, Svalbard Sheet B11G.)

Dowdeswell, J.A., G.S. Hamilton and J.O. Hagen. 1991. The duration of the active phase on surge-type glaciers: contrasts between Svalbard and other regions. J. Glaciol., 37(127), $388-400$

Dowdeswell, J.A., R. Hodgkins, A.-M. Nuttall, J.O. Hagen and G.S. Hamilton. 1995. Mass balance change as a control on the frequency and occurrence of glacier surges in Svalbard, Norwegian High Arctic. Geophys. Res. Lett., 22(21), 2909-2912.

Echelmeyer, K., R. Butterfield and D. Cuillard. 1987. Some observations on a recent surge of Peters Glacier, Alaska, USA J. Glaciol., 33(115), 341-345. 
Glasser, N.F., D. Huddart and M.R. Bennett. 1998. Ice-marginal characteristics of Fridtjovbreen (Svalbard) during its recent surge. Polar Res., 17(1), 93-100.

Gudmundsson, G.H., A. Bassi, M. Vonmoos, A. Bauder, U.H. Fischer and M. Funk. 2000. High-resolution measurements of spatial and temporal variations in surface velocities of Unteraargletscher, Bernese Alps, Switzerland. Ann. Glaciol., 31, 63-68.

Hagen, J.O. 1987. Glacier surge at Usherbreen, Svalbard. Polar Res., 5(2), n.s., 239-252.

Hagen, J.O. and O. Liestøl. 1990. Long-term glacier mass-balance investigations in Svalbard, 1950-88. Ann. Glaciol., 14, 102-106.

Hagen, J.O., O. Liestøl, E. Roland and T. Jørgensen. 1993. Glacier atlas of Svalbard and Jan Mayen. Nor. Polarinst. Medd. 129.

Hamberg, A. 1905. Astronomische, photogrammetrische und erdmagnetische Arbeiten der von A.G. Nathorst geleiteten schwedischen Polarexpedition 1898. K. Sven. Vetenskapsakad. Handl., 39(6), 1-62.

Hambrey, M.J. and J.A. Dowdeswell. 1997. Structural evolution of a surge-type polythermal glacier: Hessbreen, Svalbard. Ann. Glaciol., 24, 375-381.

Hamilton, G.S. 1992. Investigations of surge-type glaciers in Svalbard. (Ph.D. thesis, University of Cambridge.)

Hamran, S.-E., D.T. Gjessing, J. Hjelmstad and E. Aarholt. 1995. Ground penetrating synthetic pulse radar: dynamic range and modes of operation. J. Appl. Geophys., 33(3), 7-14.

Harrison, W.D., K.A. Echelmeyer, E.F. Chacho, C.F. Raymond and R.J. Benedict. 1994. The 1987-88 surge of West Fork Glacier, Susitna Basin, Alaska, USA J. Glaciol., 40(135), 241-254.

Hjelle, A. 1993. Svalbards geologi. Nor. Polarinst. Polarhåndbok 7.

Hodgkins, R. 1994. The seasonal evolution of meltwater discharge, quality and routing at a High-Arctic glacier. (Ph.D. thesis, University of Cambridge.)

Hooke, R.LeB., P. Calla, P. Holmlund, M. Nilsson and A. Stroeven. 1989. A 3 year record of seasonal variations in surface velocity, Storglaciären, Sweden. J. Glaciol., 35(120), 235-247.

Hubbard, A., H. Blatter, P. Nienow, D. Mair and B. Hubbard. 1998. Comparison of a three-dimensional model for glacier flow with field data from Haut Glacier d'Arolla, Switzerland. J. Glaciol., 44(147), 368-378.

Iken, A., H. Röthlisberger, A. Flotron and W. Haeberli. 1983. The uplift of Unteraargletscher at the beginning of the melt season a consequence of water storage at the bed? J. Glaciol., 29(101), $28-47$.

Jiskoot, H., P. Boyle and T. Murray. 1998. The incidence of glacier surging in Svalbard: evidence from multivariate statistics. Computers Geosci., 24(4), 387-399.

Jiskoot, H., T. Murray and P. Boyle. 2000. Controls on the distribution of surge-type glaciers in Svalbard. J. Glaciol., 46(154), 412-422.

Kamb, B. and 7 others. 1985. Glacier surge mechanism: 19821983 surge of Variegated Glacier, Alaska. Science, 227(4686), 469-479.

Kotlyakov, V.M. and Yu.Ya. Macheret. 1987. Radio echo-sounding of sub-polar glaciers in Svalbard: some problems and results of Soviet studies. Ann. Glaciol., 9, 151-159.
Lawson, W. 1997. Spatial, temporal and kinematic characteristics of surges of Variegated Glacier, Alaska. Ann. Glaciol., 24, 95-101.

Liestøl, O. 1974. Glaciological work in 1972. Nor. Polarinst. Årbok 1972, 125-135.

Liestøl, O. 1976. Glaciological work in 1974. Nor. Polarinst. Årbok 1974, 183-194.

Liestøl, O. 1988. The glaciers in the Kongsfjorden area, Spitsbergen. Nor. Geogr. Tidsskr., 42(4), 231-238.

McMeeking, R.M. and R.E. Johnson. 1986. On the mechanics of surging glaciers. J. Glaciol., 32(110), 120-132.

Meier, M.F. and A. Post. 1969. What are glacier surges? Can. J. Earth Sci., 6(4), Part 2, 807-817.

Meier, M.F., W.B. Kamb, C.R. Allen and R.P. Sharp. 1974. Flow of Blue Glacier, Olympic Mountains, Washington, USA J. Glaciol., 13(68), 187-212.

Melvold, K. and J.O. Hagen. 1998. Evolution of a surge-type glacier in its quiescent phase: Kongsvegen, Spitsbergen, 1964-95. J. Glaciol., 44(147), 394-404.

Murray, T., D.L. Gooch and G.W. Stuart. 1997. Structures within the surge front at Bakaninbreen, Svalbard, using ground-penetrating radar. Ann. Glaciol., 24, 122-129.

Murray, T. and 6 others. 2000. Glacier surge propagation by thermal evolution at the bed. J. Geophys. Res., 105(B6), 13,491-13,507.

Nuttall, A.-M., J.O. Hagen and J. Dowdeswell. 1997. Quiescentphase changes in velocity and geometry of Finsterwalderbreen, a surge-type glacier in Svalbard. Ann. Glaciol., 24, 249-254.

Nye, J.F. 1952. The mechanics of glacier flow. J. Glaciol., 2(12), 82-93.

Nye, J.F. 1965. The flow of a glacier in a channel of rectangular, elliptic or parabolic cross-section. J. Glaciol., 5(41), 661-690.

Ødegård, R.S., J.O. Hagen and S.-E. Hamran. 1997. Comparison of radio-echo sounding $(30-1000 \mathrm{MHz})$ and high-resolution borehole-temperature measurements at Finsterwalderbreen, southern Spitsbergen, Svalbard. Ann. Glaciol., 24, 262-267.

Pinglot, J.F., M. Pourchet, B. Lefauconnier and M. Creseveur. 1997. Equilibrium line and mean annual mass balance of Finsterwalderbreen, Spitsbergen, determined by in situ and laboratory gamma-ray measurements of nuclear test deposits. Ann. Glaciol., 24, 54-59.

Rabus, B.T. and K.A. Echelmeyer. 1997. The flow of a polythermal glacier: McCall Glacier, Alaska, USA J. Glaciol., 43(145), 522-536.

Raymond, C.F. 1980. Temperate valley glaciers. In Colbeck, S.C., ed. Dynamics of snow and ice masses. New York, Academic Press, 79-139.

Robin, G. deQ. 1986. Water blocking on surging glaciers and ice streams. Mitt. Versuchsanst. Wasserbau, Hydrol. Glaziol. Eidg. Technischen Hochsch. Zürich, 90,91.

Rolstad, C., J. Amlien, J.O. Hagen and B. Lundén. 1997. Visible and near-infrared digital images for determination of ice velocities and surface elevation during a surge on Osbornebreen, a tidewater glacier in Svalbard. Ann. Glaciol., 24, 255-261.

Schytt, V. 1969. Some comments on glacier surges in eastern Svalbard. Can. J. Earth Sci., 6(4), Part 2, 867-873.

Young, G.J. 1981. The mass balance of Peyto Glacier, Alberta, Canada, 1965 to 1978. Arct. Alp. Res., 13(3), 307-318. 